Artykuły Studia luridica Lublinensia 23, 2014

KAMIL SIKORA

\title{
Szczególny status gmin uzdrowiskowych w Polsce
}

Special status of health resort municipalities in Poland

mina stanowi w Polsce $\mathrm{z}$ jednej strony jednostkę zasadniczego po-
działu administracyjnego, $\mathrm{z}$ drugiej podstawową jednostkę samo-
rządu terytorialnego. Jej funkcjonowanie opiera się m.in. na treści przepisów rozdziału VII Konstytucji RP z dnia 2 kwietnia 1997 r., ${ }^{1}$ lecz przede wszystkim przepisów ustawy z dnia 8 marca 1990 r. o samorządzie gminnym (u.s.g.). ${ }^{2}$ Gmina uzdrowiskowa to szczególny typ gminy samorządowej w Polsce. Podstawy organizacyjno-prawne jej funkcjonowania reguluje wspomniana ustawa o samorządzie gminnym, natomiast jej status jako uzdrowiska, a także katalog zadań, jakie realizuje gmina uzdrowiskowa, określił ustawodawca w treści ustawy z dnia 28 lipca 2005 r. o lecznictwie uzdrowiskowym, uzdrowiskach i obszarach ochrony uzdrowiskowej oraz o gminach uzdrowiskowych. ${ }^{3}$

Pierwsze wzmianki o powstaniu uzdrowisk na ziemiach polskich pochodzą z przełomu XII i XIII wieku. W ówczesnym czasie doszło do powstania takich uzdrowisk, jak: Cieplice, Lądek-Zdrój i Szczawno. ${ }^{4} \mathrm{~W}$ kolejnych wiekach, wraz z rozwojem medycyny i lecznictwa uzdrowiskowego, postępował dynamiczny rozwój uzdrowisk w Polsce. W XVII wieku doceniono walory lecznicze Buska, Ciechocinka, Dusznik, Kołobrzegu, Kudowy, Nałęczowa, Połczyna czy Inowrocławia. Ważne z punktu widzenia rozwoju polskiego lecznictwa zdrojowego było uchwalenie w listopadzie 1891 r. ustawy o zdrojowiskach, przygotowanej

${ }^{1}$ Dz. U. nr 78, poz. 483.

${ }^{2}$ T.j. Dz. U. z 2013 r., poz. 594 ze zm.

${ }^{3}$ T.j. Dz. U. z 2012 r., poz. 651 ze zm.

${ }^{4}$ W końcu XI w. księżniczka Judyta, żona króla Władysława Hermana, stosowała siarczane kąpiele lecznicze w Inowłodzu nad Pilicą. Z 1281 r. pochodzi akt nadania zakonowi Joanitów ze Strzegomia źródeł wód mineralnych w Cieplicach Śląskich oraz Lądku. T. Kozłowska-Szczęsna, Stan badań klimatu i bioklimatu Polski, Dokumentacja Geograficzna nr 16, PAN, Warszawa 2000, s. 5. 
przez Komisję ds. Balneologii, Klimatologii i Hydrologii Krajowej. ${ }^{5}$ Przedmiotem regulacji ustawy była działalność uzdrowisk leżących na obszarze Galicji, miała ona znaczący wpływ na rozwój uzdrowisk położonych na tym obszarze. Pomimo nieuchwalenia podobnej ustawy na terenie pozostałych zaborów, również tam nastąpił znaczny rozwój uzdrowisk dzięki działalności towarzystw naukowych w zaborze pruskim i efektywnemu zarządzaniu w zaborze rosyjskim. ${ }^{6}$

Przełomowe dla gmin uzdrowiskowych w Polsce było uchwalenie pierwszej ustawy z dnia 23 marca 1922 r. o uzdrowiskach. ${ }^{7}$ Ustawa w treści art. 2 wprowadziła po raz pierwszy pojęcie uzdrowiska, za które uważano: zdrojowiska - czyli miejscowości posiadające cieplice albo zdroje lecznicze, stacje badawcze oraz kąpieliska morskie. Pojawiło się również pojęcie uzdrowiska o charakterze użyteczności publicznej, do których zaliczano uzdrowiska państwowe, a także uzdrowisko Zakopane i zakłady zdrojowe w Inowrocławiu.

Gmina mogła ubiegać się o status uzdrowiska o charakterze użyteczności publicznej, jeżeli: 1) posiadała zdroje o stwierdzonych właściwościach leczniczych lub też wyjątkowe warunki klimatyczne, względnie posiadała zdroje lecznicze mające zapewniony dostateczny dopływ wody leczniczej o stałym naturalnym składzie chemicznym, zabezpieczone od zepsucia i zużytkowane za pomocą odpowiednich urządzeń technicznych; 2) uzdrowisko znajdowało się w miejscowości, w której nie było poważnych przeszkód do zapewnienia nieodzownych warunków sanitarnych, posiadało też konieczne urządzenia zdrowotne i lecznicze. ${ }^{8}$ Uzdrowiska posiadające charakter użyteczności publicznej korzystały ze specjalnej opieki państwa. Zasady, na jakich pomoc była udzielana w każdym poszczególnym wypadku, ustalał Minister Spraw Wewnętrznych w porozumieniu z Ministrem Skarbu i Ministrem Robót Publicznych. ${ }^{9}$ Uzdrowisko, któremu przyznano charakter użyteczności publicznej, zgodnie z treścią art. 10 ustawy o uzdrowiskach, powinno mieć własny statut oraz plan zabudowania. Do czasu nadania statutu uzdrowisko rządziło się statutem tymczasowym, który nadawał wojewoda przy współdziałaniu wydziału wojewódzkiego z głosem stanowczym. Statut taki wyznaczał prowizorycznie granice uzdrowiska, okręgu ochrony sanitarnej oraz organizację komisji uzdrowiskowej. Wznoszenie lub przekształcanie budowli i urządzeń w uzdrowisku mogło być dokonane jedynie zgodnie z zatwierdzonym planem zabudowania. Statut uzdrowiska, po zasięgnięciu opinii Państwowej Rady do spraw Uzdrowisk, nadawał Minister Spraw Wewnętrznych w porozumieniu z zainteresowanymi ministrami i ogłaszał go w Dzienniku Urzędowym.

${ }^{5}$ Komisja powstała w końcu stycznia 1877 r. w Krakowie.

${ }^{6}$ A. R. Szromek (red.), Uzdrowiska i ich funkcja turystyczno-lecznicza, Kraków 2012, s. 16 i nast.

${ }^{7}$ Dz. U. nr 31, poz. 254.

${ }^{8}$ Art. 4 ustawy o uzdrowiskach.

${ }^{9}$ Art. 8 ustawy o uzdrowiskach. 
W treści statutu określał: a) granice uzdrowiska, b) granice okręgów ochronnych: sanitarnego i górniczego, c) organizację komisji uzdrowiskowej, zarządzającej sprawami uzdrowiska (zdrojowej, klimatycznej, kąpielowej). Plan zabudowania sporządzała właściwa komisja uzdrowiskowa, obejmował on program regulacji istniejącego stanu miejscowości, sprawy rozbudowy i upiększenia uzdrowiska. Plany zabudowania uzdrowiska zatwierdzał Minister Robót Publicznych w porozumieniu z Ministrem Zdrowia Publicznego oraz z zainteresowanymi ministrami. Każde uzdrowisko powinno posiadać: a) urządzenia zapewniające dostateczne zaopatrzenie w dobrą wodę do picia; b) urządzenia należycie usuwające wody ściekowe i odpadki; c) pomieszczenia izolacyjne dla dotkniętych chorobami zakaźnymi oraz dla obsługującej ich służby pielęgniarskiej; d) urządzenia do odkażania; e) dom przedpogrzebowy. ${ }^{10}$

Po II wojnie światowej dnia 17 czerwca 1966 r. uchwalono nową ustawę o uzdrowiskach i lecznictwie uzdrowiskowym ${ }^{11}$, która uchylała dotychczas obowiązującą ustawę z dnia 23 marca 1922 r. o uzdrowiskach. Zgodnie z treścią art. 1 uchwalonej ustawy Rada Ministrów mogła uznać za uzdrowisko - w drodze rozporządzenia - miejscowość (miasto, gminę lub część gminy), uwzględniając posiadanie warunków niezbędnych do prowadzenia lecznictwa uzdrowiskowego. Uznanie miejscowości za uzdrowisko miało na celu tworzenie warunków sprzyjających rozwojowi lecznictwa uzdrowiskowego oraz prowadzeniu działalności wypoczynkowo-turystycznej. Granicami uzdrowiska będącego miastem, osiedlem lub gromadą były granice administracyjne tych miejscowości.

Za lecznictwo uzdrowiskowe uznano zorganizowaną działalność w zakresie jak najszerszego zapobiegania chorobom i ich leczenie przy wykorzystaniu warunków naturalnych, a zatem właściwości leczniczych klimatu i krajobrazu (klimatoterapia), naturalnych zasobów leczniczych, jak wody lecznicze, gazy lecznicze i peloidy (balneoterapia), właściwości leczniczych morza (talassoterapia), a także innych czynników środowiskowych mających korzystny wpływ na wyniki świadczeń zapobiegawczych i leczniczych. Za zakłady lecznictwa uzdrowiskowego uznano te, których podstawowym zadaniem było udzielanie świadczeń zapobiegawczych i leczniczych przy wykorzystaniu warunków naturalnych i czynników środowiskowych. ${ }^{12}$

W celu zapewnienia warunków niezbędnych do prowadzenia i rozwijania lecznictwa uzdrowiskowego dla każdego uzdrowiska ustanowiono statut ${ }^{13}$, który w swojej treści określał:1) granice uzdrowiska, jeżeli ma być nim część gromady, 2) obszar ochrony uzdrowiskowej, 3) rodzaje czynności, które ze względu

\footnotetext{
${ }^{10}$ Art. 5 ustawy o uzdrowiskach.

${ }^{11}$ Dz. U. nr 23, poz. 150.

${ }^{12}$ Art. 2 ustawy o uzdrowiskach i lecznictwie uzdrowiskowym.

${ }^{13}$ Wzorcowy statut został określony w treści uchwały Rady Ministrów nr 168 z dnia 28 maja 1968 r. w sprawie wzorcowego statutu uzdrowiska, „Monitor Polski” nr 27, poz. 174.
} 
na ich oddziaływanie na warunki naturalne i czynniki środowiskowe mogły być podejmowane na obszarze ochrony uzdrowiskowej wyłącznie w szczególnym trybie określonym w przepisach ustawy. Załącznikami do statutu były decyzje o utworzeniu obszaru górniczego dla poszczególnych złóż wód leczniczych lub gazów leczniczych, jeżeli złoża występowały na obszarze ochrony uzdrowiskowej. Obszar ochrony uzdrowiskowej w zależności od potrzeb i ukształtowanych warunków naturalnych mógł być większy lub mniejszy od uzdrowiska, bądź też wspólny dla dwu i więcej uzdrowisk. ${ }^{14}$ Prezydium Wojewódzkiej Rady Narodowej uzgadniało projekt statutu uzdrowiska z Ministrem Zdrowia i Opieki Społecznej, przewodniczącym Głównego Komitetu Kultury Fizycznej i Turystyki oraz z ministrami (kierownikami urzędów centralnych) właściwymi ze względu na zagospodarowanie obszaru ochrony uzdrowiskowej.

Statut uzdrowiska uchwalała Wojewódzka Rada Narodowa właściwa ze względu na położenie danej miejscowości, w porozumieniu z Wojewódzką Komisją Związków Zawodowych i po uzyskaniu orzeczenia Ministra Zdrowia i Opieki Społecznej. Uchwała wchodziła w życie z dniem uznania przez Radę Ministrów jakiejś miejscowości za uzdrowisko ${ }^{15}$, rady narodowe miały zapewniać warunki umożliwiające jak najszersze wykorzystanie właściwości leczniczych danego uzdrowiska. W miejscowościach uznanych za uzdrowiska rady narodowe powoływały stałe komisje uzdrowiskowo-wczasowe, zapewniające odpowiednie przedstawicielstwo związków zawodowych i specjalistów.

Zwierzchni nadzór nad lecznictwem uzdrowiskowym sprawował Minister Zdrowia i Opieki Społecznej, przy którym działała Naczelna Rada Uzdrowisk i Wczasów Pracowniczych jako organ opiniodawczy i wnioskujący. Do zakresu jej działania należały sprawy działalności i planowego rozwoju lecznictwa uzdrowiskowego i uzdrowisk, z uwzględnieniem spraw wczasów pracowniczych i turystyki w miejscowościach uznanych za uzdrowiska, a także sprawy współpracy w tym zakresie właściwych organów i instytucji. W skład Naczelnej Rady Uzdrowisk i Wczasów Pracowniczych wchodzili przedstawiciele zainteresowanych naczelnych (centralnych) organów administracji państwowej, ogólnokrajowej organizacji międzyzwiązkowej oraz znawcy problematyki uzdrowiskowej.

Przy prezydiach wojewódzkich rad narodowych mogły być powołane wojewódzkie rady uzdrowisk i wczasów pracowniczych jako organy opiniodawcze i wnioskujące tych prezydiów. ${ }^{16}$ Szczególne rozwiązanie prawne zawarte zostało w treści art. 14 i 15 ustawy o uzdrowiskach i lecznictwie uzdrowiskowym, z których wynikało, że Rada Ministrów mogła rozciągnąć w drodze rozporządzenia niektóre przepisy dotyczące uzdrowisk na obszary, które posiadały warunki

\footnotetext{
${ }^{14}$ Art. 3 ustawy o uzdrowiskach i lecznictwie uzdrowiskowym.

${ }^{15}$ Art. 4 ustawy o uzdrowiskach i lecznictwie uzdrowiskowym.

${ }^{16}$ Art. 11 ustawy o uzdrowiskach i lecznictwie uzdrowiskowym.
} 
do prowadzenia lecznictwa uzdrowiskowego lub eksploatacji naturalnych zasobów leczniczych, a nie zostały uznane za uzdrowiska, mogła także w drodze rozporządzenia rozciągnąć niektóre przepisy ustawy na miejscowości, które nie prowadziły lecznictwa uzdrowiskowego, lecz posiadały wybitne walory turystyczno-wypoczynkowe, dostosowując te przepisy odpowiednio do charakteru takich miejscowości.

Na podstawie art. 17 ust. 2 ustawy z dnia 17 czerwca 1966 r. o uzdrowiskach i lecznictwie uzdrowiskowym, Minister Zdrowia i Opieki Społecznej wydał zarządzenie z dnia 25 lipca 1967 r. w sprawie wykazu miejscowości uznanych za uzdrowiska. ${ }^{17}$ Są to: Busko-Zdrój, Ciechocinek, Cieplice Śląskie-Zdrój, Czerniawa, Długopole-Zdrój, Duszniki-Zdrój, Goczałkowice-Zdrój, Horyniec-Zdrój, Inowrocław, Iwonicz-Zdrój, Jastrzębie-Zdrój, Jedlina-Zdrój, Kamień Pomorski, Kołobrzeg, Konstancin-Jeziorna, Krynica, Kudowa-Zdrój, Lądek-Zdrój, Muszyna, Nałęczów, Piwniczna, Polanica-Zdrój, Połczyn-Zdrój, Rabka, Rymanów-Zdrój, Skolimów, Solec, Swoszowice, Szczawnica, Szczawno-Zdrój, Świeradów-Zdrój, Świnoujście, Ustroń, Wapienne, Wieniec-Zdrój, Wysowa, Żegiestów-Zdrój.

Zasadnicze zmiany w zakresie funkcjonowania gmin uzdrowiskowych w Polsce wprowadził ustawodawca przepisami aktualnie obowiązującej ustawy z dnia 28 lipca 2005 r. o lecznictwie uzdrowiskowym, uzdrowiskach i obszarach ochrony uzdrowiskowej oraz o gminach uzdrowiskowych. ${ }^{18}$ Uchyliła ona przepisy dotychczasowej ustawy z dnia 17 czerwca 1966 r. o uzdrowiskach i lecznictwie uzdrowiskowym. Ustawa określa zasady oraz warunki prowadzenia i finansowania lecznictwa uzdrowiskowego, prowadzenia w nim nadzoru, kierunki lecznicze uzdrowisk, zasady nadawania obszarowi statusu uzdrowiska albo statusu obszaru ochrony uzdrowiskowej i ich pozbawiania, zadania gmin uzdrowiskowych. Ustawodawca wprowadza m.in. definicję uzdrowiska, obszaru ochrony uzdrowiskowej, stref ochronnych oraz - po raz pierwszy - pojęcie gminy uzdrowiskowej.

Zgodnie z treścią art. 2 pkt. 2 i 3 ustawy, gminą uzdrowiskową określamy taką, której obszarowi lub jego części został nadany status uzdrowiska w celu wykorzystania i ochrony znajdujących się na jego obszarach naturalnych surowców leczniczych i prowadzenia lecznictwa uzdrowiskowego. Z treści przepisów ustawy wynika, iż obecnie lecznictwo uzdrowiskowe jest integralną częścią systemu ochrony zdrowia ${ }^{19} \mathrm{i}$ stanowi zorganizowaną działalność polegającą na udzielaniu świadczeń opieki zdrowotnej z zakresu leczenia uzdrowiskowego albo rehabilitacji uzdrowiskowej, prowadzoną w uzdrowisku przez zakłady lecznictwa uzdrowiskowego albo poza uzdrowiskiem - w szpitalach i sanatoriach znajdujących się w urządzonych podziemnych wyrobiskach górniczych - przy wykorzystaniu

17 „Monitor Polski” nr 45, poz. 228.

${ }^{18}$ T.j. Dz. U. z 2012 r., poz. 651 ze zm.

${ }^{19}$ Art. 4 ust. 1 ustawy o lecznictwie uzdrowiskowym, uzdrowiskach i obszarach ochrony uzdrowiskowej oraz o gminach uzdrowiskowych. 
warunków naturalnych, takich jak: właściwości naturalnych surowców leczniczych, właściwości lecznicze klimatu, w tym talasoterapia i subterraneoterapia, oraz właściwości lecznicze mikroklimatu, a także towarzyszące zabiegi z zakresu fizjoterapii. ${ }^{20}$

Ustawodawca w treści art. 34 ust. 1 ustawy stwierdza wyraźnie, iż aby dany obszar uzyskał status uzdrowiska, musi on łącznie spełniać następujące warunki: 1) posiadać złoża naturalnych surowców leczniczych o potwierdzonych właściwościach leczniczych; 2) posiadać klimat o właściwościach leczniczych; 3) na jego obszarze muszą znajdować się zakłady lecznictwa uzdrowiskowego i urządzenia lecznictwa uzdrowiskowego, przygotowane do prowadzenia lecznictwa uzdrowiskowego; 4) wypełniać określone w przepisach o ochronie środowiska wymagania w stosunku do środowiska, są to m.in. wymagania odnoszące się do czystości powietrza, gleby czy jakości wody; 5) posiadać infrastrukturę techniczną w zakresie gospodarki wodno-ściekowej, energetycznej, w zakresie transportu zbiorowego, a także prowadzić gospodarkę odpadami.

Jeżeli na obszarze danej gminy nie znajdują się zakłady lecznictwa uzdrowiskowego lub nie ma urządzeń do jego prowadzenia, ustawodawca - zgodnie z treścią art. 34 ust. 2 ustawy - daje możliwość uzyskania przez dany obszar statusu obszaru ochrony uzdrowiskowej. Następuje to, gdy łącznie spełnione są następujące warunki: 1) posiadanie złoża naturalnych surowców leczniczych oraz klimat o właściwościach leczniczych; 2) spełnianie określononych w przepisach o ochronie środowiska wymagań w stosunku do środowiska, m.in. wymagania odnoszące się do czystości powietrza, gleby czy jakości wody; 3) posiadanie infrastruktury technicznej w zakresie gospodarki wodno-ściekowej, energetycznej, w zakresie transportu zbiorowego, a także prowadzenie gospodarki odpadami.

Jak zauważa J. Kraś, przy uwzględnieniu kryterium położenia możemy wyróżnić cztery rodzaje uzdrowisk, są to uzdrowiska: nadmorskie - położone w odległości nie większej jak $3 \mathrm{~km}$ od morza; nizinne - położone do wysokości nie większej jak 200 m n.p.m.; podgórskie - leżące na wysokości od 200 do $400 \mathrm{~m}$ n.p.m.; górskie - położone na wysokości od 400 do 800 m n.p.m. Uzdrowiska pełnią zasadniczo dwie funkcje: leczniczo-rehabilitacyjną oraz ściśle turystyczną. ${ }^{21}$ Działają w nich zakłady lecznictwa uzdrowiskowego, które utworzone zostały w celu udzielania świadczeń zdrowotnych.

Zakładami lecznictwa uzdrowiskowego są: szpitale uzdrowiskowe, sanatoria uzdrowiskowe, szpitale i sanatoria uzdrowiskowe dla dzieci, przychodnie uzdrowiskowe, zakłady przyrodolecznicze, szpitale i sanatoria w urządzonych

\footnotetext{
${ }^{20}$ Art. 2 pkt 1 ustawy o lecznictwie uzdrowiskowym, uzdrowiskach i obszarach ochrony uzdrowiskowej oraz o gminach uzdrowiskowych.

${ }^{21}$ J. Kraś, Istota i znaczenie turystyki uzdrowiskowej w Polsce, Seminare 2011, t. 29, s. 152 i nast.
} 
podziemnych wyrobiskach górniczych. ${ }^{22} \mathrm{~W}$ uzdrowiskach znajdują się różnego rodzaju urządzenia lecznictwa uzdrowiskowego, do których zaliczamy: pijalnie uzdrowiskowe, tężnie, parki, ścieżki ruchowe, urządzone odcinki wybrzeża morskiego, lecznicze i rehabilitacyjne baseny uzdrowiskowe, urządzone odpowiednio podziemne wyrobiska górnicze. ${ }^{23}$

Gmina ubiegająca się o nadanie danemu obszarowi statusu uzdrowiska albo statusu obszaru ochrony uzdrowiskowej zobowiązana jest uzyskać (w formie świadectwa) potwierdzenie właściwości leczniczych naturalnych surowców leczniczych i właściwości leczniczych klimatu.Potwierdzenie właściwości leczniczych naturalnych surowców leczniczych i właściwości leczniczych klimatu odbywa się na podstawie udokumentowanych badań poświadczających te właściwości oraz wykluczających negatywne ich oddziaływanie na organizm ludzki. Aktualnie potwierdzenia właściwości leczniczych naturalnych surowców leczniczych oraz właściwości leczniczych klimatu dokonują uprawnione przez ministra właściwego do spraw zdrowia następujące jednostki: Państwowy Zakład Higieny Instytut Naukowo-Badawczy, Instytut Geografii i Przestrzennego Zagospodarowania PAN, Instytut Meteorologii i Gospodarki Wodnej, Ośrodek Badań i Kontroli Środowiska, Główny Instytut Górnictwa, Politechnika Wrocławska. ${ }^{24}$

Kolejnym etapem dla gminy ubiegającej się o nadanie danemu obszarowi statusu uzdrowiska albo statusu obszaru ochrony uzdrowiskowej jest sporządzenie tzw. operatu uzdrowiskowego, w celu określenia możliwości prowadzenia lecznictwa uzdrowiskowego na tym obszarze. ${ }^{25}$ Operat uzdrowiskowy jest dokumentem zawierającym charakterystykę wyodrębnionego obszaru danej gminy pod względem możliwości uznania go za uzdrowisko albo za obszar ochrony uzdrowiskowej, ze szczególnym uwzględnieniem dostępnych na tym terenie naturalnych surowców leczniczych i klimatu. ${ }^{26}$

Przygotowywany jest on w formie pisemnej, z podziałem na część opisową oraz graficzną. Część opisowa operatu uzdrowiskowego sporządzana jest dodatkowo w formie elektronicznej, gdzie uwzględnia się: 1) nazwę gminy; 2) określenie obszaru, który będzie objęty wystąpieniem o nadanie statusu uzdrowiska albo

${ }^{22}$ Art. 6 ustawy o lecznictwie uzdrowiskowym, uzdrowiskach i obszarach ochrony uzdrowiskowej oraz o gminach uzdrowiskowych.

${ }^{23}$ Art. 5 ust. 1 ustawy o lecznictwie uzdrowiskowym, uzdrowiskach i obszarach ochrony uzdrowiskowej oraz o gminach uzdrowiskowych.

${ }^{24}$ Wykaz jednostek zawierają obwieszczenia Ministra Zdrowia w sprawie wykazu jednostek uprawnionych do potwierdzania właściwości leczniczych naturalnych surowców leczniczych i właściwości leczniczych klimatu - z dnia 17 lipca 2007 r., Dz. Urz. MZ nr 12, poz. 65, z dnia 18 stycznia 2008 r., Dz. Urz. MZ nr 1, poz. 4 oraz z dnia 14 lipca 2009 r., Dz. Urz. MZ nr 6, poz. 35.

${ }^{25}$ Art. 39 ust. 1 ustawy o lecznictwie uzdrowiskowym, uzdrowiskach i obszarach ochrony uzdrowiskowej oraz o gminach uzdrowiskowych.

${ }^{26}$ Art. 2 pkt 5 ustawy o lecznictwie uzdrowiskowym, uzdrowiskach i obszarach ochrony uzdrowiskowej oraz o gminach uzdrowiskowych. 
statusu obszaru ochrony uzdrowiskowej; 3 ) opis zagospodarowania przestrzennego obszaru, z uwzględnieniem powierzchni i granic stref ochrony uzdrowiskowej, dokładnych danych o lokalizacji i stanie infrastruktury technicznej, w tym komunikacyjnej, oraz prowadzonych robotach budowlanych dotyczących tej infrastruktury, a także terenów przeznaczonych w miejscowym planie zagospodarowania przestrzennego lub studium uwarunkowań i kierunków zagospodarowania przestrzennego gminy pod lecznictwo uzdrowiskowe oraz działalność rekreacyjno-wypoczynkową i działalność gospodarczą; 4) projektowane strefy ochrony uzdrowiskowej wraz z określeniem koniecznych do zachowania terenów zieleni i terenów biologicznie czynnych; 5) opis właściwości leczniczych naturalnych surowców leczniczych i właściwości leczniczych klimatu na obszarze, który wystąpił o nadanie statusu uzdrowiska albo statusu obszaru ochrony uzdrowiskowej; 6) świadectwa potwierdzające właściwości lecznicze naturalnych surowców leczniczych i właściwości lecznicze klimatu; 7) informacje na temat działających zakładów lecznictwa uzdrowiskowego oraz urządzeń lecznictwa uzdrowiskowego lub dane o planach w tym zakresie; 8) wskazanie kierunków leczniczych i przeciwwskazań dla przyszłego uzdrowiska; 9) opis istniejących obszarów i terenów górniczych ze wskazaniem, zgodnie z przepisami prawa geologicznego i górniczego, ich wyznaczonych granic lub projektowanego położenia, nazwy kopaliny głównej oraz towarzyszącej; 10) informacje o ujęciach wody, sieci wodno-kanalizacyjnej, oczyszczalniach ścieków, gospodarce odpadami oraz o mogących wystąpić zagrożeniach ekologicznych; 11) informacje o stanie czystości powietrza oraz natężeniu hałasu, opracowane zgodnie z odrębnymi przepisami; 12) datę sporządzenia i podpis wójta (burmistrza, prezydenta miasta).

Część graficzna operatu uzdrowiskowego obejmuje mapy obszaru, któremu ma zostać nadany status uzdrowiska albo status obszaru ochrony uzdrowiskowej, z zaznaczeniem poszczególnych planowanych stref ochrony uzdrowiskowej oraz ich graficznym przedstawieniem. ${ }^{27}$

Jak wynika z treści art. 40 ustawy o lecznictwie uzdrowiskowym, uzdrowiskach i obszarach ochrony uzdrowiskowej oraz o gminach uzdrowiskowych, przygotowany operat uzdrowiskowy gmina przesyła ministrowi właściwemu do spraw zdrowia w celu potwierdzenia spełnienia warunków koniecznych do nadania statusu uzdrowiska albo statusu obszaru ochrony uzdrowiskowej obszarowi, dla którego sporządzono operat uzdrowiskowy Jeżeli ustawowe przesłanki zostały spełnione, minister $\mathrm{w}$ drodze decyzji potwierdza możliwości prowadzenia lecznictwa uzdrowiskowego na obszarze będącym przedmiotem operatu uzdrowiskowego. W sytuacji gdy operat środowiskowy nie zawiera wymaganych ustawą danych lub informacji, minister właściwy do spraw zdrowia występuje do gminy

${ }^{27}$ Art. 39 ust. 4 i 5 ustawy o lecznictwie uzdrowiskowym, uzdrowiskach i obszarach ochrony uzdrowiskowej oraz o gminach uzdrowiskowych. 
o ich uzupełnienie. Nieuzupełnienie przez gminę informacji w terminie 3 miesięcy od dnia otrzymania wystąpienia ministra stanowi podstawę do wydania decyzji o odmowie potwierdzenia możliwości prowadzenia lecznictwa uzdrowiskowego na obszarze, dla którego sporządzono operat uzdrowiskowy. ${ }^{28}$ Minister właściwy do spraw zdrowia, po potwierdzeniu spełnienia warunków niezbędnych do uzyskania statusu uzdrowiska albo statusu obszaru ochrony uzdrowiskowej, występuje do Rady Ministrów z wnioskiem o nadanie danemu obszarowi statusu uzdrowiska albo statusu obszaru ochrony uzdrowiskowej.

Rada Ministrów, w drodze rozporządzenia, nadaje danemu obszarowi status uzdrowiska albo status obszaru ochrony uzdrowiskowej, określając: 1) nazwę uzdrowiska albo nazwę obszaru ochrony uzdrowiskowej; 2) granice obszaru uzdrowiska albo granice obszaru ochrony uzdrowiskowej, z uwzględnieniem właściwości leczniczych występujących na tym obszarze naturalnych surowców leczniczych i właściwości leczniczych klimatu. ${ }^{29}$ Minister właściwy do spraw zdrowia prowadzi rejestr uzdrowisk i obszarów ochrony uzdrowiskowej. ${ }^{30}$ Zgodnie z treścią art. 41 ustawyo lecznictwie uzdrowiskowym, uzdrowiskach i obszarach ochrony uzdrowiskowej oraz o gminach uzdrowiskowych, rada gminy po uzyskaniu decyzji o potwierdzeniu możliwości prowadzenia lecznictwa uzdrowiskowego zobowiązana jest uchwalić, na podstawie operatu uzdrowiskowego, statut uzdrowiska lub statut obszaru ochrony uzdrowiskowej.

Statut uzdrowiska albo statut obszaru ochrony uzdrowiskowej zawiera w szczególności: 1) nazwę uzdrowiska lub nazwę obszaru ochrony uzdrowiskowej i określenie jego granic; 2) określenie powierzchni obszaru uzdrowiska wraz z opisem stref ochrony uzdrowiskowej; 3) przepisy mające na celu ochronę funkcji leczniczej w uzdrowiskach, określające w szczególności: formy i miejsca prowadzenia punktów sprzedaży pamiątek, wyrobów ludowych, produktów regionalnych lub towarów o podobnym charakterze, formy i miejsca lokalizacji tablic i urządzeń reklamowych; 4) opis właściwości naturalnych surowców leczniczych występujących na terenie uzdrowiska albo obszaru ochrony uzdrowiskowej i właściwości leczniczych klimatu; 5) część graficzną określającą strefy ochrony uzdrowiskowej. Dodatkowo powinien on zawierać wykaz zakładów lecznictwa uzdrowiskowego i urządzeń lecznictwa uzdrowiskowego oraz kierunków leczniczych ustalonych przez ministra właściwego do spraw zdrowia.

Rada gminy uchwala statut uzdrowiska lub statut obszaru ochrony uzdrowiskowej w terminie 30 dni od dnia wejścia w życie rozporządzenia Rada Mi-

\footnotetext{
${ }^{28}$ Art. 40 ust. 4 ustawy o lecznictwie uzdrowiskowym, uzdrowiskach i obszarach ochrony uzdrowiskowej oraz o gminach uzdrowiskowych.

${ }^{29}$ Art. 42 ust. 1 i 2 ustawy o lecznictwie uzdrowiskowym, uzdrowiskach i obszarach ochrony uzdrowiskowej oraz o gminach uzdrowiskowych.

${ }^{30}$ Art. 42 ust. 3 ustawy o lecznictwie uzdrowiskowym, uzdrowiskach i obszarach ochrony uzdrowiskowej oraz o gminach uzdrowiskowych.
} 
nistrów, nadającego danemu obszarowi status uzdrowiska albo status obszaru ochrony uzdrowiskowej. ${ }^{31} \mathrm{Na}$ terenach tych każda gmina musi wydzielić trzy strefy ochronne, oznaczone literami „A”, „B”, „C”. ${ }^{32}$

Strefa „A” obejmuje obszar, na którym są zlokalizowane lub planowane zakłady lecznictwa uzdrowiskowego i urządzenia lecznictwa uzdrowiskowego, a także inne obiekty służące lecznictwu uzdrowiskowemu lub obsłudze pacjenta lub turysty, w zakresie nieutrudniającym funkcjonowanie lecznictwa uzdrowiskowego (są to w szczególności: pensjonaty, restauracje lub kawiarnie). Procentowy udział terenów zieleni wynosi tu nie mniej niż 65\%. W strefie „A" zabrania się: budowy zakładów przemysłowych, budynków mieszkalnych jedno- i wielorodzinnych. Zakaz ten nie dotyczy modernizacji istniejących obiektów, jednak nie może być zwiększona powierzchnia ich zabudowy Zakazuje się również budowy: garaży wolno stojących, obiektów handlowych o powierzchni użytkowania większej niż $400 \mathrm{~m}^{2}$, stacji paliw oraz punktów dystrybucji produktów naftowych, autostrad i dróg ekspresowych, parkingów naziemnych przy sanatoriach o liczbie miejsc postojowych większej niż 30 oraz parkingów naziemnych przed obiektami usługowymi o liczbie miejsc postojowych nie większej niż 10 .

W strefie „A" nie mogą powstawać urządzenia emitujące fale elektromagnetyczne, np. stacje bazowe telefonii ruchomej, radiowe stacje nadawcze i telewizyjne oraz stacje radiolokacyjne z wyjątkiem urządzeń łączności na potrzeby służb bezpieczeństwa publicznego i ratownictwa. Zakazuje się również budowy obiektów, które oddziałują w znacznym stopniu na środowisko. Są to w szczególności: warsztaty samochodowe, wędzarnie czy garbarnie, jednakże mogą powstawać obiekty budowlane mające służyć poprawie stanu sanitarnego uzdrowiska, takie jak: sieć wodno-kanalizacyjna, sieć gazowa i kotłownie gazowe. Można dokonywać również wierceń w celu wykorzystywania wód leczniczych. Niedopuszczalna jest natomiast budowa zapór piętrzących wodę na rzekach oraz elektrowni wodnych i wiatrowych. W obrębie tej strefy nie mogą funkcjonować składowiska odpadów stałych i płynnych, punkty skupu złomu czy skupu produktów rolnych. Nie można też składować nawozów sztucznych, środków chemicznych i opału. Zabrania się uruchamiania pól biwakowych i campingowych oraz budowy domków turystycznych. Ograniczeniu podlega też prowadzenie targowisk, można tylko prowadzić sprzedaż pamiątek, wyrobów ludowych i produktów regionalnych, lecz odbywać się to może wyłącznie w formie i miejscach wskazanych przez gminę.

W strefie „A” zakazane jest prowadzenie działalności rolniczej oraz trzymanie zwierząt gospodarskich. Nie mogą być organizowane rajdy samochodowe

${ }^{31}$ Art. 41 ust. 3 ustawy o lecznictwie uzdrowiskowym, uzdrowiskach i obszarach ochrony uzdrowiskowej oraz o gminach uzdrowiskowych.

${ }^{32}$ Art. 38 ustawy o lecznictwie uzdrowiskowym, uzdrowiskach i obszarach ochrony uzdrowiskowej oraz o gminach uzdrowiskowych. 
i imprezy masowe, które mogłyby zakłócić proces leczenia lub ciszę nocną, od godz. 22 do godz. 6.00, z wyjątkiem imprez znajdujących się w harmonogramie gminnym. Zabronione jest pozyskiwanie surowców mineralnych innych niż naturalne surowce lecznicze, wyrąb drzew oraz prowadzenia robót melioracyjnych i innych działań mogących spowodować niekorzystną zmianę istniejących stosunków wodnych. Nie można też prowadzić działań mających negatywny wpływ na fizjografię uzdrowiska, układ urbanistyczny lub jego klimat. ${ }^{33}$

Strefa „B”, dla której procentowy udział terenów zieleni wynosi nie mniej niż $50 \%$, obejmuje obszar przyległy do strefy „A" i stanowiący jej otoczenie. Jest on przeznaczony dla niemających negatywnego wpływu na właściwości lecznicze uzdrowiska lub obszaru ochrony uzdrowiskowej oraz nieuciążliwych dla pacjentów - obiektów: usługowych, turystycznych, rekreacyjnych, w tym hoteli, sportowych i komunalnych, a także budownictwa mieszkaniowego oraz innych związanych z zaspokajaniem potrzeb osób przebywających na tym obszarze, lub jest objęty granicami parku narodowego lub rezerwatu przyrody, albo jest lasem, morzem lub jeziorem..$^{34} \mathrm{~W}$ strefie „B” (podobnie jak w strefie „A”) zabrania się: budowy stacji paliw bliżej niż $500 \mathrm{~m}$ od granicy strefy „A” ochrony uzdrowiskowej, urządzeń emitujących fale elektromagnetyczne, będących przedsięwzięciami mogącymi zawsze znacząco oddziaływać na środowisko, parkingów naziemnych liczących powyżej 50 miejsc postojowych, z wyjątkiem podziemnych i naziemnych parkingów wielopoziomowych, wyrębu drzew leśnych i parkowych, z wyjątkiem cięć pielęgnacyjnych i wyrębu określonego w planie urządzania lasu.

Zabrania się także: prowadzenia robót melioracyjnych i innych działań powodujących niekorzystną zmianę istniejących stosunków wodnych, prowadzenia działań mających negatywny wpływ na fizjografię uzdrowiska i jego układ urbanistyczny lub właściwości lecznicze klimatu, a także pozyskiwania surowców mineralnych innych niż naturalne surowce lecznicze oraz uruchamiania składowisk odpadów stałych i płynnych, punktów skupu złomu i punktów skupu produktów rolnych, składów nawozów sztucznych, środków chemicznych i składów opału. ${ }^{35}$

Do strefy „B” przylega strefa „C”, która stanowi jej otoczenie i obejmuje obszar mający wpływ na zachowanie walorów krajobrazowych, klimatycznych oraz ochronę złóż naturalnych surowców leczniczych. W strefie tej procentowy udział terenów biologicznie czynnych wynosi nie mniej niż 45\% ${ }^{36} \mathrm{Na}$ obszarze

${ }^{33}$ Art. 38a ust. 1 ustawy o lecznictwie uzdrowiskowym, uzdrowiskach i obszarach ochrony uzdrowiskowej oraz o gminach uzdrowiskowych.

${ }^{34}$ Art. 38 pkt 2 ustawy o lecznictwie uzdrowiskowym, uzdrowiskach i obszarach ochrony uzdrowiskowej oraz o gminach uzdrowiskowych.

${ }^{35}$ Art. 38a ust. 2 ustawy o lecznictwie uzdrowiskowym, uzdrowiskach i obszarach ochrony uzdrowiskowej oraz o gminach uzdrowiskowych.

${ }^{36}$ Art. 38 pkt 3 ustawy o lecznictwie uzdrowiskowym, uzdrowiskach i obszarach ochrony uzdrowiskowej oraz o gminach uzdrowiskowych. 
strefy „C" zabrania się: prowadzenia robót melioracyjnych i innych działań powodujących niekorzystną zmianę istniejących stosunków wodnych, prowadzenia działań mających negatywny wpływ na fizjografię uzdrowiska i jego układ urbanistyczny lub właściwości lecznicze klimatu, pozyskiwania surowców mineralnych innych niż naturalne surowce lecznicze, a także wyrębu drzew leśnych i parkowych, z wyjątkiem cięć pielęgnacyjnych $\mathrm{i}$ wyrębu określonego w planie urządzenia lasu. ${ }^{37}$

NSA w Warszawie w wyroku z dnia 2 grudnia 2010 r., II OSK 1990/10², orzekł, iż skoro obszar uzdrowiska wydziela się w celu wykorzystania i ochrony znajdujących się na jego obszarze naturalnych surowców leczniczych, zaś lecznictwo uzdrowiskowe prowadzone jest przy wykorzystaniu warunków naturalnych, takich jak: właściwości naturalnych surowców leczniczych, właściwości leczniczych klimatu, mikroklimatu, to dla określenia zakazów obowiązujących w strefach ochronnych znaczenie mają przede wszystkim indywidualne uwarunkowania danego uzdrowiska.

Przepis art. 38a ustawy o lecznictwie uzdrowiskowym, uzdrowiskach i obszarach ochrony uzdrowiskowej oraz o gminach uzdrowiskowych zawiera regulację ogólną dotyczącą wszystkich uzdrowisk, natomiast z przyczyn oczywistych nie uwzględnia ona indywidualnych uwarunkowań konkretnych uzdrowisk. Te indywidualne uwarunkowania jest zobowiązany uwzględnić lokalny prawodawca w statucie uzdrowiska, uchwalonym na podstawie sporządzonego uprzednio operatu uzdrowiska. ${ }^{39}$

Regulacja zakazów zawartych w treści art. 38a ustawy o lecznictwie uzdrowiskowym, uzdrowiskach i obszarach ochrony uzdrowiskowej oraz o gminach uzdrowiskowych nie wyłącza statutowej regulacji zakazów, wynikających z indywidualnych uwarunkowań danego uzdrowiska. Przepis art. 38a ustawy samodzielnie w pełni nie reguluje zakresu czynności zakazanych w poszczególnych strefach, co oznacza, że ustawodawca poprzez treść art. 41 ust. 1 i 2 ustawy upoważnia radę gminy do samodzielnego uregulowania $\mathrm{w}$ treści statutu czynności zabronionych, wynikających $\mathrm{z}$ indywidualnych uwarunkowań danego uzdrowiska. ${ }^{40}$

Gmina, która na podstawie decyzji ministra właściwego do spraw zdrowia uzyska potwierdzenie możliwości prowadzenia lecznictwa uzdrowiskowego na swoim obszarze, sporządza i uchwala miejscowy plan zagospodarowania przestrzennego dla strefy „A” ochrony uzdrowiskowej, na zasadach określonych w ustawie z dnia 27 marca 2003 r. o planowaniu i zagospodarowaniu przestrzen-

\footnotetext{
${ }^{37}$ Art. 38a ust. 3 ustawy o lecznictwie uzdrowiskowym, uzdrowiskach i obszarach ochrony uzdrowiskowej oraz o gminach uzdrowiskowych.

${ }^{38}$ LEX nr 786780.

${ }^{39}$ Wyrok NSA w Warszawie z dnia 2 grudnia 2010 r., II OSK 1990/10, LEX nr 786780.

${ }^{40}$ Wyrok WSA we Wrocławiu z dnia 8 grudnia 2011 r., IV SA/Wr 504/11, LEX nr 1155180.
} 
nym (Dz. U. nr 80, poz. 717 ze zm.), w terminie do 2 lat od dnia otrzymania tej decyzji ${ }^{41}$ Podany przez ustawodawcę termin określić należy jako ustawowy, o charakterze instrukcyjnym. Jest on sformułowany bezpośrednio w ustawie, ale jednocześnie po jego upływie uprawnienie gminy do sporządzenia i uchwalenia planu miejscowego nie wygasa. ${ }^{42}$ Nieuchwalenie miejscowego planu zagospodarowania przestrzennego wbrew obowiązkowi wynikającemu $\mathrm{z}$ art. $38 \mathrm{~b}$ ustawy o lecznictwie uzdrowiskowym, uzdrowiskach i obszarach ochrony uzdrowiskowej oraz o gminach uzdrowiskowych, powodujące niemożność zagospodarowania i zabudowy nieruchomości, narusza interes prawny wynikający z przysługującego prawa własności, co daje legitymację do wniesienia skargi na bezczynność w trybie art. 101 a ust. 1 u.s.g. ${ }^{43}$

Jak wynika z treści art. 43 ustawy o lecznictwie uzdrowiskowym, uzdrowiskach i obszarach ochrony uzdrowiskowej oraz o gminach uzdrowiskowych, gmina, na której obszarze znajduje się uzdrowisko lub obszar ochrony uzdrowiskowej, zobowiązana jest, nie rzadziej niż raz na 10 lat, do sporządzenia i przedstawienia ministrowi właściwemu do spraw zdrowia operatu uzdrowiskowego w celu potwierdzenia spełniania przez jej obszar albo jego część wymogów ustawowych. W sytuacji gdy na podstawie złożonego operatu uzdrowiskowego minister właściwy do spraw zdrowia stwierdzi nieprawidłowości, wyznacza on nie dłuższy niż 5 lat okres dostosowawczy w celu ich usunięcia. W przypadku nieusunięcia nieprawidłowości, minister właściwy do spraw zdrowia występuje do Rady Ministrów o wydanie rozporządzenia o pozbawieniu danego obszaru statusu uzdrowiska lub statusu obszaru ochrony uzdrowiskowej. Statut uzdrowiska lub statut obszaru ochrony uzdrowiskowej traci moc z dniem wejścia w życie rozporządzenia.

Jeżeli ustały warunki uzasadniające nadanie danemu obszarowi statusu uzdrowiska albo statusu obszaru ochrony uzdrowiskowej, minister właściwy do spraw zdrowia występuje do gminy o podjęcie działań koniecznych w celu przywrócenia tych warunków. W sytuacji gdy gmina w terminie 5 lat nie przywróci warunków, Rada Ministrów, na wniosek ministra właściwego do spraw zdrowia, w drodze rozporządzenia, pozbawia dany obszar takiego statusu. ${ }^{44}$

Do nazwy miejscowości, w której granicach administracyjnych znajduje się obszar uzdrowiska, może zostać dodany odpowiednio wyraz „zdrój”, w sytuacji gdy podstawą leczenia uzdrowiskowego są wody lecznicze lub wyraz „cieplice” bądź „uzdrowisko termalne”, jeżeli podstawą leczenia uzdrowiskowego są wody

\footnotetext{
${ }^{41}$ Art. 38b ustawy o lecznictwie uzdrowiskowym, uzdrowiskach i obszarach ochrony uzdrowiskowej oraz o gminach uzdrowiskowych.

${ }^{42}$ Wyrok NSA w Warszawie z dnia 19 maja 2011 r., II OSK 426/11, LEX nr 1081783; wyrok WSA w Gdańsku z dnia 25 listopada 2010 r., II SA/Gd 459/10, LEX nr 661867.

${ }^{43}$ Wyrok WSA w Gdańsku z dnia 10 listopada 2010 r., II SAB/Gd 30/10, LEX nr 756030.

${ }^{44}$ Art. 44 ustawy o lecznictwie uzdrowiskowym, uzdrowiskach i obszarach ochrony uzdrowiskowej oraz o gminach uzdrowiskowych.
} 
termalne. ${ }^{45}$ Zmiany nazw miejscowości dokonywane są na zasadach określonych w ustawie z dnia 29 sierpnia 2003 r. o urzędowych nazwach miejscowości i obiektów fizjograficznych. ${ }^{46}$

Do zakresu działalności gminy należą wszystkie sprawy publiczne o znaczeniu lokalnym, niezastrzeżone ustawami na rzecz innych podmiotów. Gminie jako podstawowej jednostce samorządu terytorialnego przysługuje domniemanie kompetencji w wykonywaniu zadań o charakterze lokalnym. Art. 7 ust. 1 ustawy o samorządzie gminnym stanowi, że do zadań własnych gminy należy zaspokajanie zbiorowych potrzeb wspólnoty, m.in.: ładu przestrzennego, gospodarki nieruchomościami, ochrony środowiska i przyrody oraz gospodarki wodnej, gminnych dróg, ulic, mostów, placów oraz organizacji ruchu drogowego, wodociągów i zaopatrzenia w wodę, kanalizacji, usuwania i oczyszczania ścieków komunalnych, utrzymania czystości i porządku oraz urządzeń sanitarnych, wysypisk i unieszkodliwiania odpadów komunalnych, zaopatrzenia w energię elektryczną i cieplną oraz gaz, działalności w zakresie telekomunikacji, lokalnego transportu zbiorowego, ochrony zdrowia, pomocy społecznej, w tym ośrodków i zakładów.

Jak wynika z treści art. 46 ustawy o lecznictwie uzdrowiskowym, uzdrowiskach i obszarach ochrony uzdrowiskowej oraz o gminach uzdrowiskowych, gmina uzdrowiskowa oraz gmina posiadająca status obszaru ochrony uzdrowiskowej - poza zadaniami przewidzianymi przepisami ustawy z dnia 8 marca 1990 r. o samorządzie gminnym - realizują zadania własne związane z zachowaniem funkcji leczniczych uzdrowiska, w szczególności w zakresie: 1) gospodarki terenami, z uwzględnieniem potrzeb lecznictwa uzdrowiskowego, ochrony złóż naturalnych surowców leczniczych oraz budowy lub innych czynności zabronionych w poszczególnych strefach ochrony uzdrowiskowej; 2) ochrony warunków naturalnych uzdrowiska lub obszaru ochrony uzdrowiskowej oraz spełniania wymagań w zakresie dopuszczalnych norm zanieczyszczeń powietrza, natężenia hałasu, odprowadzania ścieków do wód lub do ziemi, gospodarki odpadami, emisji pól elektromagnetycznych, o których mowa w odrębnych przepisach; 3) tworzenia warunków do funkcjonowania zakładów i urządzeń lecznictwa uzdrowiskowego oraz rozwoju infrastruktury komunalnej w celu zaspokajania potrzeb osób przebywających w gminie na leczeniu uzdrowiskowym; 4) tworzenia i ulepszania infrastruktury komunalnej i technicznej przeznaczonej dla uzdrowisk lub obszarów ochrony uzdrowiskowej.

Rada gminy ma możliwość powoływania stałych lub doraźnych komisji ${ }^{47}$, w przypadku gminy uzdrowiskowej lub gminy posiadającej status obszaru ochro-

\footnotetext{
${ }^{45}$ Art. 45 ustawy o lecznictwie uzdrowiskowym, uzdrowiskach i obszarach ochrony uzdrowiskowej oraz o gminach uzdrowiskowych.

${ }^{46}$ Dz. U. nr 166, poz. 1612.

${ }^{47}$ Art. 21 ust. 1 u.s.g.
} 
ny uzdrowiskowej rada gminy powołuje stałą komisję uzdrowiskową, określając przedmiot jej działania i skład osobowy. Komisja uzdrowiskowa jest organem opiniodawczo-doradczym rady gminy w sprawach dotyczących uzdrowiska oraz obszaru ochrony uzdrowiskowej. Do jej zadań należy w szczególności: opiniowanie projektu operatu uzdrowiskowego, opiniowanie projektu statutu uzdrowiska lub statutu obszaru ochrony uzdrowiskowej, opiniowanie projektów miejscowych planów zagospodarowania przestrzennego, obejmujących tereny wchodzące w skład stref ochrony uzdrowiskowej, opiniowanie gminnych programów ochrony środowiska, opiniowanie projektów programów zamierzeń inwestycyjnych gminy dotyczących obszaru uzdrowiska oraz obszaru ochrony uzdrowiskowej. ${ }^{48}$

Zasadnicze znaczenie dla gospodarki finansowej gminy uzdrowiskowej jest możliwość pobierania przez gminę opłaty uzdrowiskowej lub miejscowej. Jak wynika z treści art. 19 ustawy z dnia 12 stycznia 1991 r. o podatkach i opłatach lokalnych ${ }^{49}$, rada gminy w drodze uchwały określa zasady ustalania i poboru oraz terminy płatności i wysokość stawek opłaty uzdrowiskowej lub miejscowej. Aktualna stawka opłaty miejscowej w miejscowościach posiadających status obszaru ochrony uzdrowiskowej nie może przekroczyć kwoty 3,08 zł dzienne ${ }^{50}$, natomiast stawka opłaty uzdrowiskowej nie może przekroczyć 4,26 zł dziennie. ${ }^{51}$ Opłata miejscowa jest pobierana od osób fizycznych przebywających dłużej niż dobę w celach turystycznych, wypoczynkowych lub szkoleniowych: 1) w miejscowościach posiadających korzystne właściwości klimatyczne, walory krajobrazowe oraz warunki umożliwiające pobyt osób w tych celach; 2) w miejscowościach znajdujących się na obszarach, którym nadano status obszaru ochrony uzdrowiskowej na zasadach określonych w ustawie z dnia 28 lipca 2005 r. o lecznictwie uzdrowiskowym, uzdrowiskach i obszarach ochrony uzdrowiskowej oraz o gminach uzdrowiskowych - za każdy dzień pobytu w takich miejscowościach. ${ }^{52}$

Opłata uzdrowiskowa jest pobierana od osób fizycznych przebywających dłużej niż dobę w celach zdrowotnych, turystycznych, wypoczynkowych lub szkoleniowych w miejscowościach znajdujących się na obszarach, którym nadano status uzdrowiska za każdy dzień pobytu w takich miejscowościach. ${ }^{53}$

Opłaty miejscowej oraz uzdrowiskowej nie pobiera się: 1) pod warunkiem wzajemności - od członków personelu przedstawicielstw dyplomatycznych

${ }^{48}$ Art. 47 ustawy o lecznictwie uzdrowiskowym, uzdrowiskach i obszarach ochrony uzdrowiskowej oraz o gminach uzdrowiskowych.

${ }^{49}$ T.j. Dz.U. z 2010 r., nr 95, poz. 613 ze zm.

${ }^{50}$ Pkt 4 lit. c) obwieszczenia Ministra Finansów z dnia 2 sierpnia 2012 r. w sprawie górnych granic stawek kwotowych podatków i opłat lokalnych w 2013 r., „Monitor Polski” 2012.587.

${ }^{51}$ Pkt 4 lit. d) obwieszczenia Ministra Finansów z dnia 2 sierpnia 2012 r. w sprawie górnych granic stawek kwotowych podatków i opłat lokalnych w 2013 r. „Monitor Polski” 2012.587.

${ }^{52}$ Art. 17 ust. 1 ustawy o podatkach i opłatach lokalnych.

${ }^{53}$ Art. 17 ust. 1a ustawy o podatkach i opłatach lokalnych. 
i urzędów konsularnych oraz innych osób zrównanych z nimi na podstawie ustaw, umów lub zwyczajów międzynarodowych, jeżeli nie są obywatelami polskimi i nie mają miejsca pobytu stałego na terytorium Rzeczypospolitej Polskiej; 2) od osób przebywających w szpitalach; 3) od osób niewidomych i ich przewodników; 4) od podatników podatku od nieruchomości z tytułu posiadania domów letniskowych położonych w miejscowości, w której pobiera się opłatę miejscową albo uzdrowiskową; 5) od zorganizowanych grup dzieci i młodzieży szkolnej. ${ }^{54}$

Zabronione jest jednoczesne pobieranie opłaty miejscowej i uzdrowiskowej od tej samej osoby fizycznej..$^{55}$

Nadzór nad lecznictwem uzdrowiskowym sprawuje minister właściwy do spraw zdrowia i wojewoda, a w odniesieniu do lecznictwa uzdrowiskowego prowadzonego w zakładach lecznictwa uzdrowiskowego, utworzonych przez Ministra Obrony Narodowej i ministra właściwego do spraw wewnętrznych odpowiednio ci ministrowie w porozumieniu z ministrem właściwym do spraw zdrowia. ${ }^{56}$

Jak wynika z treści art. 20 ustawy, katalog uprawnień nadzorczych ministra właściwego do spraw zdrowia, a także wojewody nie ma charakteru zamkniętego. W szczególnością są oni uprawnieni do: 1) oceny zgodności lecznictwa uzdrowiskowego z kierunkami leczniczymi (uprawnienie w tym zakresie posiada jedynie minister właściwy do spraw zdrowia ${ }^{57}$ ); 2) żądania udostępnienia dokumentów związanych z działalnością zakładów lecznictwa uzdrowiskowego oraz zapoznawania się z ich treścią; 3) żądania przekazania wszelkich informacji i wyjaśnień dotyczących działalności zakładów lecznictwa uzdrowiskowego; 4) przeprowadzania kontroli na terenie zakładów lecznictwa uzdrowiskowego i żądania wyjaśnień potrzebnych do oceny ich działalności i jakości świadczeń opieki zdrowotnej oraz funkcjonowania zakładów lecznictwa uzdrowiskowego.

W przypadku stwierdzenia naruszenia przepisów ustawy minister właściwy do spraw zdrowia (wojewoda) powiadamia kierownika zakładu lecznictwa uzdrowiskowego o stwierdzonych nieprawidłowościach oraz wydaje zalecenia pokontrolne mające na celu usunięcie stwierdzonych nieprawidłowości,wydaje w miarę potrzeby decyzje administracyjne, nakazujące usunięcie stwierdzonych nieprawidłowości, wyznaczając termin do ich usunięcia i dostosowania działalności do

${ }^{54}$ Art. 17 ust. 2 ustawy o podatkach i opłatach lokalnych.

${ }^{55}$ A. Hanusz, P. Czerski, A. Niezgoda, Dochody budżetu jednostek samorzadu terytorialnego, Warszawa 2008, s. 164-167.

${ }^{56}$ Art. 17 ustawy o lecznictwie uzdrowiskowym, uzdrowiskach i obszarach ochrony uzdrowiskowej oraz o gminach uzdrowiskowych.

${ }^{57}$ Art. 20 ust. 1 pkt 1 w zw. z ust. 6 ustawy o lecznictwie uzdrowiskowym, uzdrowiskach i obszarach ochrony uzdrowiskowej oraz o gminach uzdrowiskowych. 
przepisów ustawy. ${ }^{58} \mathrm{~W}$ przypadku gdy został złożony wniosek o ponowne rozpatrzenie sprawy, termin do usunięcia nieprawidłowości liczy się od dnia doręczenia zalecenia lub decyzji po rozpatrzeniu wniosku.W terminie 14 dni od dnia upływu terminu wyznaczonego do usunięcia nieprawidłowości zakład lecznictwa uzdrowiskowego informuje pisemnie ministra właściwego do spraw zdrowia o sposobie usunięcia nieprawidłowości. ${ }^{59}$

Wojewoda sprawuje nadzór nad lecznictwem uzdrowiskowym prowadzonym przez zakłady lecznictwa uzdrowiskowego na obszarze województwa przy pomocy naczelnego lekarza uzdrowiska ${ }^{60}$ Wojewoda powołuje i odwołuje naczelnego lekarza uzdrowiska. Istnieje możliwość powołania naczelnego lekarza uzdrowiska dla więcej niż jednego uzdrowiska na terenie danego województwa. Wojewoda przekazuje ministrowi właściwemu do spraw zdrowia informację o powołaniu albo odwołaniu naczelnego lekarza uzdrowiska, który sprawuje nadzór nad jakością świadczeń opieki zdrowotnej udzielanych przez zakłady lecznictwa uzdrowiskowego. ${ }^{61} \mathrm{~W}$ ramach nadzoru naczelny lekarz uzdrowiska jest uprawniony w szczególności do: 1) żądania udostępnienia dokumentów związanych z działalnością zakładów lecznictwa uzdrowiskowego oraz zapoznawania się z ich treścią; 2) żądania przekazania wszelkich informacji i wyjaśnień dotyczących działalności zakładów lecznictwa uzdrowiskowego; 3) przeprowadzania kontroli na terenie zakładów lecznictwa uzdrowiskowego i żądania wyjaśnień potrzebnych do oceny ich działalności i jakości udzielanych przez nie świadczeń zdrowotnych oraz funkcjonowania tych zakładów. ${ }^{62}$ Naczelny lekarz uzdrowiska za pośrednictwem wojewody, co 12 miesięcy, składa informację o swojej działalności ministrowi właściwemu do spraw zdrowia. ${ }^{63}$ Gminy uzdrowiskowe stanowią rzeczywiście szczególny typ gmin samorządowych w Polsce, wyróżniają się nie tylko walorami uzdrowiskowo-klimatycznymi, lecz także szerszym niż zwykła gmina zakresem zadań publicznych, a także możliwością dodatkowych źródeł swojego finansowania poprzez pobieranie opłat miejscowych i uzdrowiskowych.

Obecnie w Polsce status uzdrowiska posiadają 44 gminy. Należą do nich w szczególności: Augustów, Busko-Zdrój, Ciechocinek, Cieplice Śląskie-Zdrój,

${ }^{58}$ Art. 20 ust. 3 ustawy o lecznictwie uzdrowiskowym, uzdrowiskach i obszarach ochrony uzdrowiskowej oraz o gminach uzdrowiskowych.

${ }^{59}$ Art. 20 ust. 4 i 5 ustawy o lecznictwie uzdrowiskowym, uzdrowiskach i obszarach ochrony uzdrowiskowej oraz o gminach uzdrowiskowych.

${ }^{60}$ Art. 17 ust. 2 ustawy o lecznictwie uzdrowiskowym, uzdrowiskach i obszarach ochrony uzdrowiskowej oraz o gminach uzdrowiskowych.

${ }^{61}$ Art. 24 ust. 1, 1a i 2 ustawy o lecznictwie uzdrowiskowym, uzdrowiskach i obszarach ochrony uzdrowiskowej oraz o gminach uzdrowiskowych.

${ }^{62}$ Art. 24a ust. 1 ustawy o lecznictwie uzdrowiskowym, uzdrowiskach i obszarach ochrony uzdrowiskowej oraz o gminach uzdrowiskowych.

${ }^{63}$ Art. 24 ust. 3 ustawy o lecznictwie uzdrowiskowym, uzdrowiskach i obszarach ochrony uzdrowiskowej oraz o gminach uzdrowiskowych. 
Czerniawa, Dąbki, Długopole-Zdrój, Duszniki-Zdrój, Goczałkowice-Zdrój, Gołdap, Horyniec-Zdrój Inowrocław, Iwonicz-Zdrój, Jedlina-Zdrój, Kamień Pomorski, Kołobrzeg, Konstancin-Jeziorna, Krasnobród, Krynica-Zdrój, Kudowa-Zdrój, Lądek-Zdrój, Muszyna, Nałęczów, Piwniczna-Zdrój, Polanica-Zdrój, Polańczyk, Połczyn-Zdrój, Przerzeczyn-Zdrój, Rabka-Zdrój, Rymanów-Zdrój, Solec-Zdrój, Sopot, Supraśl, Swoszowice, Szczawnica, Szczawno-Zdrój, Świeradów-Zdrój, Świnoujście, Ustka, Ustroń, Wapienne, Wieniec-Zdrój, Wysowa, Żegiestów-Zdrój. Wśród nich znajdują się uzdrowiska o znaczeniu międzynarodowym, należą do nich: Busko-Zdrój, Ciechocinek, Iwonicz-Zdrój, Krynica-Zdrój, Kudowa-Zdrój, Nałęczów, Polanica-Zdrój oraz Szczawnica.

\section{SUMMARY}

The spa municipality is a special type of local government municipalities in Poland. The legal basis of its functioning is the Act of 8 March, 1990 on the local government, but its special status as a health resort, and the list of tasks that implements the municipality's tax legislator is described in the text of the Act of 28 July, 2008 on spa treatment, spas and conservation areas of the spa and the spa municipalities.

Commune defines spa a town, where the entire area or part thereof has been given the status of the spa. The municipality applying for granting the status of a given area of the spa or health resort status is required to draw up the so-called spa sampling, in order to identify opportunities for health and spa resorts in the area.

The minister competent for health matters, after confirmation of fulfilment through the conditions necessary to obtain the status of the spa or health resort status, applies to the Council of Ministers for granting a given area the status of the spa or health resort status. The Council of Ministers, by regulation, gives the status of a given area of the spa or health resort area status.

A form of cooperation between spa municipalities is the Association of Municipalities of the Polish Republic Health Resorts whose aim is the development of Polish spas and localities of spa values, supporting the development of the spa, tourist and recreational sports in the municipalities belonging to the Association. 